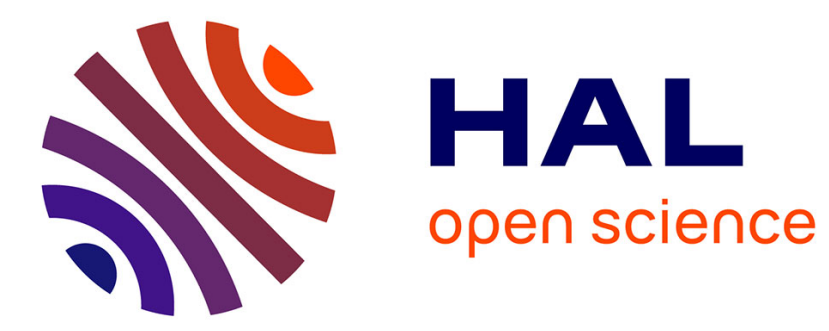

\title{
Fractionation of polyphenols from thermomechanical pulp mill process water by flotation and membrane integrated process
}

\author{
M. Courbalay, M. Villain-Gambier, A. Klem, S. Dumarçay, D. Trebouet
}

\section{To cite this version:}

M. Courbalay, M. Villain-Gambier, A. Klem, S. Dumarçay, D. Trebouet. Fractionation of polyphenols from thermomechanical pulp mill process water by flotation and membrane integrated process. Environmental Technology, 2019, 40 (24), pp.3240-3251. 10.1080/09593330.2018.1468826 . hal-02474561

\author{
HAL Id: hal-02474561 \\ https://hal.science/hal-02474561
}

Submitted on 11 Sep 2020

HAL is a multi-disciplinary open access archive for the deposit and dissemination of scientific research documents, whether they are published or not. The documents may come from teaching and research institutions in France or abroad, or from public or private research centers.
L'archive ouverte pluridisciplinaire $\mathbf{H A L}$, est destinée au dépôt et à la diffusion de documents scientifiques de niveau recherche, publiés ou non, émanant des établissements d'enseignement et de recherche français ou étrangers, des laboratoires publics ou privés. 


\section{Fractionation of polyphenols from thermomechanical pulp mill process water by flotation and membrane integrated process}

M. Courbalay ${ }^{\mathrm{a}, \mathrm{b}}$, M. Villain-Gambier ${ }^{\mathrm{a}}, \mathrm{A} . \mathrm{Klem}^{\mathrm{c}}, \mathrm{S}$. Dumarcay ${ }^{\mathrm{b}}$ and D. Trebouet ${ }^{\mathrm{a}}$.

${ }^{a}$ Laboratoire de Reconnaissance et Procédés de Séparation Moléculaire (RePSeM), Université de Strasbourg, Institut Pluridisciplinaire Hubert Curien (IPHC), UMR CNRS 7178, 25 rue Becquerel, 67087 Strasbourg Cedex 2, France

${ }^{b}$ Laboratoire d'Etudes et de Recherche sur le Matériau Bois, EA 4370 USC INRA, Boulevard des Aiguillettes, BP 70239, 54506 Vandoeuvre lès Nancy, France

${ }^{c}$ Norske Skog Golbey, Route Jean-Charles Pellerin, BP 109, 88194 Golbey, France

Corresponding author:

Maud Villain-Gambier

Email: maud.villain@unistra.fr 


\title{
Fractionation of polyphenols from thermomechanical pulp mill process water by flotation and membrane integrated process
}

\begin{abstract}
Fractionation of phenolic compounds in thermomechanical pulp mills was performed with a coupling of a prior treatment realized by flotation and a ceramic membrane process. Two lines of membranes filtration were tested. After a common $150 \mathrm{kDa}$ clarification, $1 \mathrm{kDa}$ filtration was performed with or without previous $5 \mathrm{kDa}$ filtration. Flotation was shown to be inevitable to retain lipophilic compounds which cause severe membrane fouling. $150 \mathrm{kDa}$ permeate flux was $20 \%$ higher when process water was firstly floated and was around $260 \mathrm{~L} \cdot \mathrm{h}^{-1} \cdot \mathrm{m}^{-2} .1 \mathrm{kDa}$ membrane was fouled with $31 \%$ of irreversible fouling without previous $5 \mathrm{kDa}$ filtration and phenolic compounds purity reached only $26 \%$ in this $1 \mathrm{kDa}$ permeate. Phenolic compounds as lignin-like substances which might be attached to hemicelluloses were recovered in $5 \mathrm{kDa}$ retentate. Retentate of $1 \mathrm{kDa}$ might contain a major fraction of lignin derivatives with molecular weights around $1 \mathrm{kDa}$ free or linked with phenolic acids. Permeate of $1 \mathrm{kDa}$ contained $14 \%$ of phenolic compounds such as lignans and free phenolic acids purified at 50 $\%$.
\end{abstract}

Keywords: phenolic compounds, thermomechanical pulp mills, membrane process, flotation, lignin derivatives and lignans.

\section{Introduction}

Process water from thermomechanical pulp (TMP) mills are enriched in wood soluble extractives as phenolic compounds with molecules such as lignin-like substances, lignans, and phenolic acids. This process water is not easily biodegradable because phenolic compounds can be considered as toxic constituents for biomass used in pulped mill wastewater treatment plant. With the adequate separation techniques, the phenolic content of TMP process water could be considered as valuable by-products since they have been proven to offer great benefits to human health [1] in the prevention of diseases associated with oxidative stress [2]. They could also found industrial applications as natural additives with antimicrobial and/or antioxidant properties, i.e. in the cosmetic and food industries [3]. It is the case for lignans which can have possible applications in the fields of pharmacy and nutrition [4]. 7hydroxymatairesinol (HMR), the predominant lignan in knots of Norway spruce wood (Picea abies) [5], which is discarded during processing for paper in Nordic countries has already found a commercial application as dietary supplement under the name HMRlignan ${ }^{\mathrm{TM}}$ [6]. Lignan quantities to extract could be of interest as Puro et al. [7] published that TMP process water of a mixture softwood/hardwood could commonly contain around $60 \mathrm{mg} . \mathrm{L}^{-1}$ of lignans. Lignin could also found applications. Arkell et al. [8] have listed the potential valorization of lignin removed from the black liquor of kraft pulp mill. They mentioned that lignin could be used as biofuel [9], as precursor for carbon fibres [10], as emulsifiers [11] or in phenolic resins [12]. Phenolic compounds can contribute to the economic potential of TMP process as it was already assessed for olive oil production industry with olive mill wastewater (OMW) 
valorization with its phenolic content. Zagklis and Paraskeva [13] estimated that value of phenolic extracts from OMW could reach $5 € \cdot \mathrm{mg}^{-1}$ if high purity is obtained.

The combination of membrane filtration is a promising technology to concentrate and purify phenolic compounds present in TMP process water. This technology was already used by Persson et al. $[14,15]$ to concentrate galactoglucomannans (GGM) which are the main hemicelluloses in process water resulting from softwood TMP mill. Authors mentioned that membrane filtration is a suitable separation technique to use when molecules of interest are present in a low concentration. They announced that a $5 \mathrm{kDa}$ hydrophilic polysulfone membrane had high hemicelluloses retention of $90 \%$ independent of flux and pressure for filtration of process water from a TMP pulp mill process water. Thuvander and Jönsson [16] obtained hemicelluloses purity around $70 \%$ in a $5 \mathrm{kDa}$ retentate of TMP process water from spruce wood previously microfiltrated (mean pore size of $0.1 \mu \mathrm{m}$ ). Another advantage of membrane process is that chemicals are not required to perform the separation. However, the choice of membrane (material, cut off), operating conditions, number of filtration stages should be considered carefully to maximize permeate flux and phenolic compounds recovery and also limit the main drawback of membrane process: membrane fouling. Phenolic compounds were already concentrated thanks to membrane process for agro-industrial wastewater as OMW $[17,18,19]$. Lignin of black liquor from kraft pulp mill was already fractioned by membrane filtrations. Mänttäri et al. [20] removed $75 \%$ of lignin in the retentate of filtration done with a $1 \mathrm{kDa}$ membrane made of polyethersulfone. But researches are still needed in the case of phenolic compounds fractionation from TMP process water. The aim of this study was then to develop a process coupling flotation with ceramic membrane process for phenolic compounds recovery i.e. lignin derivatives, lignans and phenolic acids from TMP process water.

Prior to membrane filtration, the TMP process water was pretreated by flotation. This step was necessary for the removal of lipophilic molecules which can cause severe membrane fouling [7]. Process water from TMP mills contains a fraction of lipophilic extractives called wood pitch which is composed mainly of fatty and resin acids, sterols, steryl esters and triglycerides. These compounds are partially dissolved in the water phase and were associated with the colloidal pitch droplets [21]. Zasadowski et al. [22] found a concentration of lipophilic extractives in spruce TMP process water of $309 \mathrm{mg} \cdot \mathrm{L}^{-1}$. With their flotation device improved with a foaming agent (160 ppm of cationic dodecyltrimetylammoniumchloride (DoTAC)) $85 \%$ of total lipophilic extractives were retained.

A loss of phenolic compounds is however expected during flotation. Zasadowski et al. [22] found that lignans were retained at $10 \%$ with their flotation system enhanced by utilization of DoTAC foaming agent. Then a $150 \mathrm{kDa}$ filtration was carried out to remove suspended matter and turbidity. Two lines were then tested on $150 \mathrm{kDa}$ permeate, the line 1 was composed of a $5 \mathrm{kDa}$ stage to concentrate the hemicelluloses [15] followed by a $1 \mathrm{kDa}$ filtration to retain lignin [20] and purify phenolic acids and lignans in the $1 \mathrm{kDa}$ permeate. The line 2 consisted on a single $1 \mathrm{kDa}$ filtration to assess the possibility of membrane process simplification. The choices of membrane cut off were decided in agreement with a previous study [15] which has shown that $63 \%$ of hemicelluloses and $22 \%$ of lignin-like substances were retained by a $5 \mathrm{kDa}$ membrane which was made of hydrophilized polyethersulphone. The authors 
announced that hemicelluloses mainly composed of galactoglucomannans (GGM) were concentrated but also purified in this $5 \mathrm{kDa}$ retentate as lignin substances and also inorganic ions and monosaccharides were removed in the $5 \mathrm{kDa}$ permeate.

The flux declines were evaluated and the compositions of retentates and permeates were assessed considering dry matter, suspended matter, total polyphenols and polysaccharides to determine the more appropriate line for fractionation of phenolic compounds.

\section{Material and methods}

\section{1- Process water}

Process water came from a TMP mill (Norske Skog) producing pulp from resinous wood (mix of spruces and pines) located in France. $333 \mathrm{~L}$ of clear filtrates were sampled from the disc filters after refiners and vat latency $\left(45 \mathrm{~min}\right.$ at $\left.85^{\circ} \mathrm{C}\right)$. Refining line worked at 4 bars of pressure and $90^{\circ} \mathrm{C}$. Flotation was performed immediately after process water collection. Afterwards process water was directly sent to Strasbourg University where it was stocked at $4^{\circ} \mathrm{C}$. The average $\mathrm{pH}$ was $6.2 \pm 0.3$.

\section{2- Flotation}

Flotation was performed directly after process water sampling at $70^{\circ} \mathrm{C}$. Flotation was used to remove lipophilic substances as fatty and resin acids due to their fouling properties. A Voith Sulzer cell of $35 \mathrm{~L}$ was used. Flotation was optimized thanks to turbidity decrease kinetics. An air flow rate of 9 L.min ${ }^{-1}$ was applied during 30 min under constant mechanic agitation to homogenize air bubble repartition in the cell. Agitation was performed with a helix system attached at the cell bottom.

\section{3- Experimental filtration procedure}

The membrane set up used was stainless steel made and contained a $70 \mathrm{~L}$ feed tank (Firmus, France). During the entire filtration procedure temperature of TMP process water was set at $60^{\circ} \mathrm{C}$. After flotation, process water was filtered with a $150 \mathrm{kDa}$ membrane. Permeate of UF $150 \mathrm{kDa}$ filtration was either used on line 1 or 2 (Figure 1).

The optimized operating conditions (i.e. transmembrane pressure and cross flow velocity) were determined for each filtration step in total recirculation mode. Then, the filtration experiments were conducted in concentration mode at optimized conditions where permeates were collected in a separate container and retentates were circulated back to the feed tank. Concentration mode was used for all UF and NF filtrations at optimized operating conditions previously assessed in total recycle mode (i.e. transmembrane pressure and cross flow velocity). Pressures, temperature, permeate and retentate flows were recorded on a data acquisition device (Ecograph T, Endress+hauser). Transmembrane pressure was calculated as the difference between the average pressure between the inlet and outlet pressures on membrane module and permeate pressure. Transmembrane pressure was regulated with a valve present on the retentate line. 
The temperature was measured with a Pt100 thermocouple element and controlled with a PID regulator. The volume reduction factor (VRF) was calculated as the ratio between feed and retentate volumes.

\section{4- Ultrafiltration}

The clarified effluent (2) obtained after flotation was ultrafiltered to remove suspended matter and turbidity. A Kleansep tubular ceramic membrane (reference KLMBWU3) with a cut off of $150 \mathrm{kDa}$ was used. The membrane material was $\mathrm{TiO}_{2}-\mathrm{ZrO}_{2}$. The membrane was composed of 19 channels with hydraulic diameter of $3.5 \mathrm{~mm}$ and length of $1178 \mathrm{~mm}$. The filtration area was $0.245 \mathrm{~m}^{2}$. One part (75L) of the $150 \mathrm{kDa}$ UF permeate (P1) was used as the feed solution for the following UF $5 \mathrm{kDa}$ step (reference KLMBWN2). The optimized conditions for 150 and $5 \mathrm{kDa}$ filtrations were for both UF membranes a cross flow velocity of $5 \mathrm{~m} . \mathrm{s}^{-1}$ and a transmembrane pressure of respectively 2.5 and 5.5 bars. The $5 \mathrm{kDa}$ UF was also a Kleansep membrane with the same geometry, dimensions and material than the $150 \mathrm{kDa}$ UF.

\section{5- Nanofiltration}

$1 \mathrm{kDa} \mathrm{NF}$ membrane was used to filtrate either the permeate of $5 \mathrm{kDa}$ membrane (P2) or directly the permeate of $150 \mathrm{kDa} \mathrm{UF}$ (P1) (70 L). $1 \mathrm{kDa}$ NF membrane (KLMBWN1) possessed the same characteristics than UF membranes used. NF $1 \mathrm{kDa}$ optimized conditions of filtration were a transmembrane pressure of 5.5 bars and cross flow velocity of $5 \mathrm{~m} . \mathrm{s}^{-1}$.

\section{6- Assessment of fouling mechanisms}

Two models were used to describe the fouling process. The resistance-in-series model is based on Darcy's law and a succession of cleaning was applied to distinguish the different resistances due to membrane fouling. The classification of membrane fouling used here was proposed by Meng et al. [23]. Initial flux, $\mathrm{J}_{0}$ was measured after membrane cleaning (with $\mathrm{NaOH} 10$ g.L $\mathrm{L}^{-1} ; 60^{\circ} \mathrm{C} ; 1 \mathrm{~h}$ - followed by $\mathrm{HNO}_{3} 3$ g.L. $\mathrm{L}^{-1} ; 60^{\circ} \mathrm{C} ; 1 \mathrm{~h}$ ). First fouled membrane permeability was measured after a simple cleaning with distilled water. This water cleaning was performed to take off removable fouling (i.e. the water reversible fouling) which was caused by the loosely attached foulants including concentration polarization and cake resistances $\left(\mathrm{R}_{\text {removable }}\right.$ ) simultaneously. After, chemicals cleaning (with $\mathrm{NaOH} 10$ g. $\mathrm{L}^{-1} ; 60^{\circ} \mathrm{C}$; $1 \mathrm{~h}$ - followed by $\mathrm{HNO}_{3} 3$ g. $\mathrm{L}^{-1} ; 60^{\circ} \mathrm{C} ; 1 \mathrm{~h}$ ) were carried out and the irremovable fouling (i.e. the chemical cleaning reversible fouling) which is caused by pore blocking and strongly attached foulants can be removed, thereby assessing the irremovable resistance $\left(\mathrm{R}_{\text {irremovable }}\right)$. Membrane was rinsed with distilled water between basic and acid cleanings. The residual difference between membrane resistance after filtration and chemical cleaning and initial membrane resistance was attributed to irreversible fouling $\left(\mathrm{R}_{\text {irreversible }}\right)$. The irreversible fouling is a permanent fouling which cannot be removed by any approaches. Between each cleaning step, the membrane permeability was assessed with distilled water. With the use of Eq. (1), hydraulic resistances due to each fouling kinds previously defined can be calculated and contribution of each fouling type can be obtained. 


$$
L_{P}=\frac{1}{\mu \times\left(R_{m}+R_{f}\right)} \text { with } R_{f}=R_{\text {removable }}+R_{\text {irremovable }}+R_{\text {irreversible }}
$$

With $L p$ : membrane permeability $\left(\mathrm{m}^{3} \mathrm{~m}^{-2} \mathrm{~s}^{-1} \mathrm{~Pa}^{-1}\right), R f$ : fouling hydraulic resistance $\left(\mathrm{m}^{-1}\right)$, $R m$ : intrinsic resistance of membrane $\left(\mathrm{m}^{-1}\right), \mu$ : dynamic viscosity of the permeate at $20^{\circ} \mathrm{C}$ (Pa s).

In order to evaluate the main phenomenon implied in membrane fouling installation, permeate flux decrease was analyzed through three different models [24,25]. These models consider relationship between permeate flux and filtration time in concentration procedure. In model 1 the main cause of fouling is a cake formation. Membrane characteristics are assumed to be responsible for fouling. This model is described by the following linearized equation:

$$
\frac{1}{J}=\frac{1}{J_{0}}+K t
$$

With J: permeate flux; $\mathrm{J}_{0}$ : initial flux; t: time

In model 2, cake formation is also the main fouling phenomenon but the entire surface is covered by a layer of particles. Model 2 is defined by the linearized equation 3 :

$$
\frac{1}{J^{2}}=\frac{1}{J_{0}^{2}}+K t
$$

For model 3, pore blocking is the main mechanism involved in membrane fouling. This model assumes that a fraction of pores is totally blocked by particles and this fraction is proportional to the permeate flux passing through the membrane. The linearized equation 4 described model 3:

$$
\ln J=\ln J_{0}-K t
$$

According to equations (2, 3 and 4), the plots of $1 / \mathrm{J}, 1 / \mathrm{J}^{2}$ and $\ln (\mathrm{J})$ were a function of time allow assessing the model fitting the best with permeate flux data.

\section{7 - Analyses}

Samples were dried in a rotavapor $\left(40^{\circ} \mathrm{C} ; 25\right.$ mbar) to constant weight. The dry matter was calculated by weighing of the residue.

To calculate suspended matter, samples were filtered on $0.45 \mu \mathrm{m}$ filter. The filter with the resulting filter cake was dried at $105^{\circ} \mathrm{C}$ until constant weight. As filter was initially weighted, suspended matter was obtained by difference between filter weight after filtration and before filtration. Total phenolic compounds were quantified with the Folin-Ciocalteu colorimetric method (760 nm) according to Singleton and Rossi [26] and quantified in gallic acid equivalent. Polysaccharides were quantified at $625 \mathrm{~nm}$ with colorimetric method developed by Dubois et al. [27]. The percentages of phenolic compounds and polysaccharides were calculated as the ratio between phenolic compounds or polysaccharides and dry matter 
concentrations in the specified fraction. The calculation of the different substances recovery rates were carried out from the data of figure 1 (volume) and table 1(concentration). Recovery rates of dry matter, suspended matter, total polyphenols and polysaccharides were expressed as percentages and were calculated as the ratio between the mass after the considered operation (i.e. flotation, ultrafiltration or nanofiltration) and initial mass analyzed in inlet process water. 


\section{1- Results and discussion}

\section{1- Fractionation and composition of substances in fractions}

TMP process water was separated in seven different fractions. Five fractions composed of concentrated matter (3, R1, R2, R3 and R4) and two clarified water stream (P3 and P4). Physico-chemical characteristics of all these streams are presented in table 1.

Table 2 presents the recovery rates of dry matter, suspended matter, total polyphenols and polysaccharides in the process water for the five fractions (3, R1, R2, R3 and R4). The mass balances between inlet and outlet mass for each stage were checked, within less than $10 \%$ in all cases.

A combination of flotation and UF $150 \mathrm{kDa}$ allowed retaining the major part of suspended matter and turbidity. Zasadowski et al. [22] found that flotation was effective to remove colloidal wood substances in TMP process water $\left(\mathrm{pH}=6,2 ; 70^{\circ} \mathrm{C}\right)$ as the turbidity decreased from 320 to 110 NTU due to flotation treatment. As mentioned in table 2, $46 \%$ of dry matter was rejected by flotation (3). Lipophilic extractives could be considered as the major part of this dry matter as flotation was proved as efficient in floating small suspended particles, organic matter and oil [28].

A high amount of polysaccharides ( $42 \%$ ) was rejected by the flotation. Thuvander and Jönsson [16] proved that a fraction of hemicelluloses which passed through a $0.5 \mu \mathrm{m}$ filtration could have a molecular weight higher than $100 \mathrm{kDa}$. This high mass molecular might be due to the capacity of hemicelluloses to adsorb onto the surface of colloidal materials [29].

$30 \%$ of initial dry matter was stopped by a filtration with a cut off of $150 \mathrm{kDa}$. Addition of dry matter mass recovered on line 1 (R2 and R3) corresponded well to the dry matter mass retained on line 2 (R4). Persson et al [15] showed that around $25 \%$ of hemicelluloses and 10 $\%$ of lignin-like substances of the inlet TMP pulp mill process water from spruce wood respectively concentrated at $1.15 \mathrm{~g} . \mathrm{L}^{-1}$ and $0.73 \mathrm{~g} . \mathrm{L}^{-1}$ were retained by a $0.2 \mu \mathrm{m}$ microfiltration step performed with a ceramic membrane. Polysaccharides concentration of inlet process water of the present study was in the same range at $1.66 \mathrm{~g} . \mathrm{L}^{-1}$. Polysaccharides retention with the $150 \mathrm{kDa}$ membrane was consistent with results of Persson et al. [15] as 29 $\%$ were retained in $\mathrm{R} 1$.

Only $6 \%$ of inlet polysaccharides were retained in the $5 \mathrm{kDa}$ retentate of the present study, because the major part of this fraction was previously removed by flotation (42\%) and UF $150 \mathrm{kDa}(29 \%)$. The retention of polysaccharides such as hemicelluloses by the $150 \mathrm{kDa}$ membrane although their molecular weight is in the range of 30 to $45 \mathrm{kDa}$, could be explained by the low salinity of water process $\left(8 \mathrm{mg} . \mathrm{L}^{-1}\right.$ é NaCl$)$. In these conditions, the membrane surface charges increase and allow the retention of these polysaccharides [30].

After this $5 \mathrm{kDa}$ UF step Persson et al. [15] performed a NF fractionation with a spiral composite membrane (cut off unknown ; 2517 NF99HF Alfa Laval). They mentioned that this NF retentate was composed of lignin, carbohydrates and other aromatic compounds such as 
lignans. Therefore it can be considered that NF retentate R3 was mainly constituted of phenolic compounds with low molecular weight as lignin derivatives, lignans and phenolic acids. As on line 2, step with $1 \mathrm{kDa}$ membrane was performed on UF $150 \mathrm{kDa}$ permeate (P1), the retentate (R4) was also composed of small phenolic compounds and with a larger amount of carbohydrates.

It is worth noting that the flotation and the $150 \mathrm{kDa}$ UF can be considered as efficiently pretreatment before UF $5 \mathrm{kDa}$ and/or NF $1 \mathrm{KDa}$ filtration steps (line 1 or 2). Indeed, the retention rates of suspended matter and turbidity were high after this first sequence, $80 \%$ and $99 \%$ respectively.

\section{2- Composition of phenolic compounds in all streams}

The distribution of total polyphenols content in the various stages of fractionation is shown in figure 2. The polyphenols recovery is considered as one of the objectives. Mass balances for total phenolic compounds over each stage showed differences (named error on figure 2) between the ingoing and outgoing mass expressed as percentages of less than $10 \%$ for all stages except in the line 1 for successive 5 and $1 \mathrm{kDa}$ filtrations, which indicates that the results are reliable. Error came from colorimetric dosage of phenolic compounds (experimental results are within a $\pm 5 \%$ error range) and phenolic compounds associated to membrane fouling.

According to table 2 and figure 2, a high amount of total polyphenols (44\%) was unfortunately rejected by the flotation. The high rejection of polyphenols could be explained by different intermolecular interactions such as polyphenols -colloidal lipophilic wood substances. As lipophilic content was well removed with flotation, these components could drag away polyphenols in the same time. Lipohilic compounds of TMP process water form micelle aggregates negatively charged at process water $\mathrm{pH}$ of 6.2 [31]. The most hydrophobic compounds i.e. triglycerides and steryl esters form the core of colloidal resin particles while sterols, fatty and resin acids form the thin layer of the micelles [7]. The carboxyl groups of fatty and resin acids are orientated toward the aqueous phase [32]. Carboxyl and hydroxyl groups on the surface of colloidal resin particles stabilize them electrostatically [32]. As these chemical groups were also found on polyphenols structure, they could interact with lipophilic aggregates

The accepted fraction from flotation (2) was filtered on $150 \mathrm{kDa}$ membrane. $28 \%$ of polyphenolic compounds present in this accepted fraction were rejected in retentate R1.

As the phenolic fraction found in literature with the larger molecular weight (20 kDa) was lignin derivatives [16], phenolic compounds in $150 \mathrm{kDa}$ retentate might be linked to others components. Phenolic compounds as $p$-coumaric, syringic, vanillic or ferulic acids can be bonded to lignin molecules in fast grow poplar tree by ester and ether linkages [33]. Iiayama et al. [34] suggested that all of the ferulic acid etherified to lignins was also esterified to polysaccharides as hemicelluloses. Furthermore several studies announced that lignin molecules can interact with hemicelluloses thanks to covalent bonds [35-38]. 
According to the figure 2, total polyphenols which came from UF $150 \mathrm{kDa}$ permeate (P1) was retained at $43 \%$ in R2 and $27 \%$ in R3 (line 1). Mass balances for total phenolic compounds over this stage exhibited differences between the ingoing and outgoing mass of $16 \%$. This difference indicated that a certain amount of phenolic compounds might be attached on 5 and/or $1 \mathrm{kDa}$ membrane surfaces. Retentate R2 was the result of a filtration with a $5 \mathrm{kDa}$ membrane. As showed by Persson et al. [15], the retentate of a $5 \mathrm{kDa}$ filtration of TMP process water was mainly composed of hemicelluloses (63\%) but also contained $22 \%$ of lignin. Thuvander and Jönsson [16] found in their $5 \mathrm{kDa}$ retentate of TMP process water from spruce wood a lignin fraction of $20 \mathrm{kDa}$ and affirmed that this fraction was attached to hemicelluloses. Lignin could link with hemicelluloses as it is the case in native lignocellulosic matrix [39]. Therefore phenolic compounds present in retentate $\mathrm{R} 2$ might be lignin attached to hemicelluloses molecules.

Retentate R3 was obtained after a filtration of $1 \mathrm{kDa}$. It might contain lignin derivatives with molecular weights less or around $1 \mathrm{kDa}[16]$ and also a small fraction of hydrolysed parts of polysaccharide molecules linked with phenolic compounds. Lignin fractions can also be linked with phenolic acids via ether linkage [40]. Lignin might be the major component of retentate R3 as Mänttäri et al. [20] removed $75 \%$ of lignin with a direct $1 \mathrm{kDa}$ filtration with a membrane composed of polyethersulphone skin layer.

According to the line 2, step with $1 \mathrm{kDa}$ filtration was performed on $150 \mathrm{kDa}$ UF permeate P1, retentate R4 contained all the previous molecules mentioned above. In permeates P3 and P4 phenolic compounds were present at 14 and $21 \%$ respectively. The phenolic compounds rate was of $50 \%$ in extract from P3 and $26 \%$ in extract from P4 (table 1). As on line 1 process water was submitted to an additional filtration of $5 \mathrm{kDa}, 12 \%$ of dry matter was retained with this filtration. Therefore as dry matter concentration was lower in P3 (400 mg. $\mathrm{L}^{-1}$ ) than in P4 (1100 mg. $\mathrm{L}^{-1}$ ), purity of phenolic compounds increased. They may correspond to phenolic acids or lignans with low molecular weight present in TMP process water as free phenolic acids and hydroxymatairesinol [7] with molecular weights around $200 \mathrm{Da}$ and $375 \mathrm{Da}$ respectively.

\section{3- Permeation fluxes}

Flotation was used prior to membrane process to avoid inherent membrane fouling due to fatty and resin acids contained in process water of thermomechanical pulp mill using resinous wood [7]. To attest the efficiency of the prior treatment by flotation, inlet TMP process water either floated or not was filtered on the $150 \mathrm{kDa}$ membrane with the same operating conditions. Figure 3 shows the results of relative $150 \mathrm{kDa}$ permeate flux obtained as a function of volume reduction factor for both process water previously floated or not.

$150 \mathrm{kDa}$ flux with or without prior flotation were relatively stable during concentration. Flotation was beneficial as relative permeate flux obtained for TMP process water previously floated was around $20 \%$ higher $\left(260 \mathrm{~L} \cdot \mathrm{h}^{-1} \cdot \mathrm{m}^{-2}\right)$ than permeate flux measured without flotation pretreatment at stable state. Therefore, flotation was considered as necessary prior to $150 \mathrm{kDa}$ membrane filtration. Filtration on $150 \mathrm{kDa}$ membrane was successfully performed until a VRF of 3.9 (Figure 4 a). Filtration was then stopped when sufficient P1 volume was obtained 
for the further filtrations. After flotation and $150 \mathrm{kDa}$ membrane filtration, $75 \mathrm{~L}$ of process water were filtered on line 1 and $70 \mathrm{~L}$ on line 2 . Relative permeate flux measured on line 1 (filtrations on $5 \mathrm{kDa}$ and then $1 \mathrm{kDa}$ membranes) and line 2 (filtration on $1 \mathrm{kDa}$ membrane) are presented in figure 4.5 and $1 \mathrm{kDa}$ filtrations of line 1 were done until VRF of 3.7 and 2.6 respectively. For both experiments on line 1, batch concentration mode was stopped when a final retentate volume around 20L was reached in the feed tank. At the end of both filtrations, permeate flux were around $55 \mathrm{~L} \cdot \mathrm{h}^{-1} \cdot \mathrm{m}^{-2}$ for $5 \mathrm{kDa}$ filtration and $57 \mathrm{~L} \cdot \mathrm{h}^{-1} \cdot \mathrm{m}^{-2}$ for $1 \mathrm{kDa}$ filtration. For line 2, $1 \mathrm{kDa}$ filtration was directly performed after the clarification done with the $150 \mathrm{kDa}$ membrane. Figure 4 showed that relative permeate flux rapidly decreased until a VRF of 1.8. Experiment was then stopped as $1 \mathrm{kDa}$ membrane was totally fouled. The use of $1 \mathrm{kDa}$ in the configuration of line 2 was then not optimal, because flux was low and not stable. At a VRF of 1.8, permeate flux was only at $12.5 \mathrm{~L} \cdot \mathrm{h}^{-1} \cdot \mathrm{m}^{-2}$. 


\section{4- Membrane fouling characteristics}

The effect of flotation on $150 \mathrm{kDa}$ membrane fouling was described on the figure 5 with the resistances-in-series model. The comparison of resistances showed the irremovable resistance decrease from $70 \%$ without flotation to $29 \%$ with flotation. With the flotation as pretreatment, the main fouling phenomenon was at $64 \%$ a removable fouling which was a coupling between concentration polarization and a cake layer formation. It was easily removed with distilled water while irremovable resistance was removed with sodium hydroxide cleaning solution because global membrane fouling was at $99 \%$ organic (Figure 5). According to the decrease in turbidity of $66 \%$ (from 320 to 110 NTU) with the flotation, the colloidal substances might be highly involved in the irremovable fouling of the $150 \mathrm{kDa}$ membrane. Thuvander and Jönsson [16] might confirmed the previous result as they also considered that the permeate flux decline of their $0.5 \mu \mathrm{m}$ ceramic microfiltration was due to the high amount of colloidal material present in process water from spruce wood TMP pulp mill. Puro et al. [7] have shown that the fouling layer on UF membranes leading to flux decline contained extractives arising from the colloids in the water after the filtration of process water from a chemical-thermomechanical pulp mill. $29 \%$ of polysaccharides were retained with the $150 \mathrm{kDa}$ membrane. Hemicelluloses could be also implied in the $150 \mathrm{kDa}$ membrane fouling as mentioned by Persson et al. [15]. They explained that the hemicelluloses are bound to the solid material or entrapped in the filter cake formed by retained solids on the membrane. The hypothesis about adsorption is strengthen by the observation by Willför et al. [41] that GGM can act as emulsion stabilizers of pitch droplets and that arabinan can be linked to lignin in lignin-carbohydrate complexes. Furthermore, Thuvander and Jönsson [16] proved that a fraction of hemicelluloses which passed through a $0.5 \mu \mathrm{m}$ filtration could have a molecular weight higher than $100 \mathrm{kDa}$. This high mass molecular might be due to the capacity of hemicelluloses to adsorb onto the surface of colloidal materials [29].

The evaluation of the fouling process by the models developed by Wiesner and Aptel [24] was not satisfactory for the $150 \mathrm{kDa}$ filtrations, with and without flotation (Figure 6). Indeed, the regression coefficient $\left(\mathrm{R}^{2}\right)$ is lower than 0.97 . The main phenomenon which caused the membrane fouling installation cannot be determined with this model.

Distribution of fouling resistances (Figure 5) exhibited the same characteristics for 5 and 1 $\mathrm{kDa}$ membranes of line 1 with a resistance due to removable fouling such as a concentration polarization around $78 \%$ and a resistance due to irremovable fouling of $15 \%$. For both membranes cake resistance was considered as insignificant as most of suspended matter was removed by the previous $150 \mathrm{kDa}$ filtration.

As shown in table 1, retentate R2 was mainly composed of polysaccharides (39\%) and it could be considered that the hemicelluloses were the main compounds in the $5 \mathrm{kDa}$ retentate of TMP process water as described by Thuvander and Jönsson [16] about filtration of TMP process water of spruce wood. In their study, they proposed a distribution of hemicelluloses types in relation with their molecular weights. The hemicelluloses had molecular weights between 0.2 and $70 \mathrm{kDa}$ with a dominant fraction at about $10 \mathrm{kDa}$. Above $7.7 \mathrm{kDa}$ GGM was the major hemicelluloses type, whereas between 7.7 and $1 \mathrm{kDa}$ GGM represented 60 to $80 \%$ 
of total polysaccharides and below $1 \mathrm{kDa}$, the fraction was composed almost entirely of other polysaccharides as arabinan and xylan. They reached hemicelluloses concentration of $52 \mathrm{~g} . \mathrm{L}^{-1}$ using $5 \mathrm{kDa}$ membrane with a volume reduction of $98 \%$. Moreover, they mentioned that hemicelluloses with size in the range of $0.2-0.8 \mathrm{kDa}$ passed through $5 \mathrm{kDa}$ membrane. Strand et al. [42] mentioned the existence of hemicelluloses with size in the range $0.5-5.7$ $\mathrm{kDa}$ in the retentate of a $5 \mathrm{kDa}$ polysulfone membrane coming from birch wood extracts obtained after $70 \mathrm{~min}$ at 20 bars and $173^{\circ} \mathrm{C}$. They showed that these fractions had the more negative effect on membrane flux and were responsible for $5 \mathrm{kDa}$ membrane fouling.

Retentate R2 was also composed of polyphenolic compounds as lignin molecules; the polyphenols rate was about $24 \%$ (table 1). In $5 \mathrm{kDa}$ retentate from TMP process water from spruce wood, the main part of lignin molecules had an average size of $1 \mathrm{kDa}$ but a fraction with size around $20 \mathrm{kDa}$ could be found [16]. In the native lignocellulosic matrix, hemicelluloses are cross-linked by lignin [39]. Thuvander and Jönsson [16] mentioned then that a small amount of lignin could be attached to hemicelluloses. Strand et al. [42] obtained lignin fractions with molecular weights below $10 \mathrm{kDa}$ and they affirmed that the fraction with mass in the range of 0.2-0.8 $\mathrm{kDa}$ causes a high permeation flux decline with the $5 \mathrm{kDa}$ polysulfone membrane. Based on their multivariable data analysis, authors announced that both ligneous and hemicellulosic compounds had a negative impact on filtration capacity and could be small enough to enter the membrane surface and take part of membrane fouling. Considering the results developed in the present study, permeate from UF membrane containing hemicelluloses and lignin molecules did not cause a severe fouling on $5 \mathrm{kDa}$ ceramic membrane and can be explained by the membrane ceramic material allowing higher cross flow velocity than organic membrane.

Model 3 described the best, membrane fouling occurring on $5 \mathrm{kDa}$ membrane (Figure 6) with a $\mathrm{R}^{2}$ higher than 0.99 . Therefore it could be supposed that the layer of molecules on the $5 \mathrm{kDa}$ membrane induced a pore blocking. However, this membrane fouling was assessed as irremovable fouling (figure 5) and can be removed by a chemical cleaning. For line 1, $1 \mathrm{kDa}$ membrane fouling could be well represented by models 1 and 2 with $\mathrm{R}^{2}$ higher than 0.97 . Membrane fouling was then probably caused by cake formation due to small polysaccharides as xylan, arabinan and small lignin molecules.

Distribution of hydraulic resistances of $1 \mathrm{kDa}$ membrane of line 2 showed that fouling was at $36 \%$ due to removable fouling which implied a cake formation and concentration polarization, at $27 \%$ irremovable and at $31 \%$ irreversible. The hemicelluloses fractions with size in the range $0.2-0.8 \mathrm{kDa}[16]$ and $0.5-5.7 \mathrm{kDa}$ [42] could take part in the measured irreversible fouling of $1 \mathrm{kDa}$ membrane used without previous $5 \mathrm{kDa}$ filtration. The lignin fraction studied by Strand et al. [42] with size between 0.2-0.8 $\mathrm{kDa}$ could also cause significant irreversible fouling of $1 \mathrm{kDa}$ membrane. The regression coefficient of model 3 was close to unity (0.99). It can be concluded that pore blocking was the main fouling mechanism. Therefore fractionation of process water with $5 \mathrm{kDa}$ membrane was assumed to be inevitable. 


\section{Conclusion}

Fractionation of phenolic compounds in thermomechanical pulp mills was performed with a coupling of a prior treatment realized by flotation and UF-NF membranes process at $60^{\circ} \mathrm{C}$. The flotation was considered as necessary prior to $150 \mathrm{kDa}$ membrane filtration. $150 \mathrm{kDa}$ filtration was used to clarify TMP process water and retained mainly suspended matter and colloidal substances which contain hemicelluloses may be linked to phenolic compounds such as lignin derivatives. The flotation and the $150 \mathrm{kDa}$ ultrafiltration can be considered as efficiently pretreatments before further filtration steps (line 1 or 2). Therefore two lines were tested with or without $5 \mathrm{kDa}$ filtration prior to a $1 \mathrm{kDa}$ filtration. $5 \mathrm{kDa}$ filtration was essential as without this previous step, $1 \mathrm{kDa}$ filtration was fouled at $31 \%$ in an irreversible way and phenolic components purity was only of $26 \%$ in $1 \mathrm{kDa}$ permeate. In $5 \mathrm{kDa}$ retentate $43 \%$ of phenolic compounds were present and mainly composed of lignin linked to hemicelluloses. Retentate of $1 \mathrm{kDa}$ filtration contained $24 \%$ of phenolic compounds which were probably associations between lignin and phenolic acids. Permeate of $1 \mathrm{kDa}$ filtration was then composed of free phenolic acids and lignans with a phenolic compounds purity of $50 \%$. The fractionation with $5 \mathrm{kDa}$ UF and $1 \mathrm{kDa} \mathrm{NF}$ can be considered as a preliminary efficient step for polyphenols recovery. Nonetheless, associations with others filtration steps with different membrane cut off or others techniques are recommended as aromatic exchange resins if higher phenolic compounds concentration and purity are needed.

\section{Acknowledgements}

Authors thank the "Agence De l'Environnement et de la Maîtrise de l'Energie" (a French funding agency) for funding this study within the framework of REVACOPPA project.

\section{References}

1. Yu S, Cheung KL, Li W, et al. Plant Phenolic Compounds: Biochemistry, Nutrition, and Pharmacology. Wiley; 2009.

2. Scalbert A, Manach C, Morand C, et al.. Dietary polyphenols and the prevention of diseases. Crit Rev Food Sci Nutr. 2005;45:287-306.

3. Barbosa-Pereira L, Bilbao A, Vilches P, et al. Brewery waste as a potential source of phenolic compounds: Optimisation of the extraction process and evaluation of antioxidant and antimicrobial activities. Food Chem. 2014;145:191-197.

4. Willför SM, Smeds AI, Holmbom BR. Chromatographic analysis of lignans. J Chromatogr A. 2006;1112: 64-77.

5. Ekman R, Holmbom B. Analysis by gas chromatography of the wood extractives in pulp and water samples from mechanical pulping of spruce. Nord Pulp Pap Res J. 1989;111989:16-24.

6. Wolterbeek APM, Roberts A, Korte H, et al. Prenatal developmental toxicity study with 7-hydroxymatairesinol potassium acetate (HMRlignan) in rats. Regul Toxicol Pharmacol. 2004;40:1-8. 
7. Puro L, Kallioinen M, Manttari M, et al. Evaluation of behavior and fouling potential of wood extractives in ultrafiltration of pulp and paper mill process water. J. Membr. Sci. 2011;368:150-158.

8. Arkell A, Olsson J, Wallberg O. Process performance in lignin separation from softwood black liquor by membrane filtration. Chem Eng Res Des. 2014;92: 1792-1800.

9. Axelsson E, Olsson MR, Berntsson T. Increased capacity in kraft pulp mills: lignin separation and reduced steam demand compared with recovery boiler upgrade. Nord Pulp Pap Res J. 2006;21:485-492.

10. Kubo S, Kalda JF. Lignin-based carbon fibres: effect of synthetic polymer blending on fiber properties. J Polym Environ. 2005;13:97-105.

11. Gargulak JD, Lebo SE. Lignin: historical, biological, and materials perspectives. ACS Symp.Ser. 2000;742:304-320.

12. Sellers Jr T, McGinnis GD, Ruffin TM, et al. Lignin-modified phenolic resin: synthesis optimization, adhesive strenght, and thermal stability. J Adhes Sci Technol. 2004;14:1179-1193.

13. Zagklis DP, Paraskeva CA. Membrane filtration of agro-industrial wastewaters and isolation of organic compounds with high added values. Water Sci Technol. 2014;69:202-207.

14. Persson T, Jönsson AS. Isolation of hemicelluloses by ultrafiltration of thermomechanical pulp mill process water: Influence of operating conditions. Chem Eng Res Design. 2010a;88:1548-1554.

15. Persson T, Krawczyk H, Nordin AK, et al. Fractionation of process water in thermomechanical pulp mills. Biores Technol. 2010b;101:3884-3892.

16. Thuvander J, Jönsson AS. Extraction of galactoglucomannan from thermomechanical pulp mill process water by microfiltration and ultrafiltration-Influence of microfiltration membrane pore size on ultrafiltration performance. Chem Eng Res Des. 2016;105:171-176.

17. Paraskeva CA, Papadakis VG, Tsarouchi E, et al. Membrane processing for olive mill wastewater fractionation. Desalination. 2007;213:218-229.

18. Zagklis DP, Vavouraki AI, Kornaros ME, et al. Purification of olive mill wastewater phenols through membrane filtration and resin adsorption/desorption. J Hazard Mater. 2015;285:69-76.

19. Bazzarelli F, Piacentini E, Poerio T, et al. Advances in membrane operations for water purification and biophenols recovery/valorization from OMWWs. J Membr Sci. 2016;497:402-409.

20. Mänttäri M, Lahti J, Hatakka H, et al. Separation phenomena in UF and NF in the recovery of organic acids from kraft black liquor. J Membr Sci. 2015;490:84-91.

21. Sundberg A, Strand A, Vähäsalo L, et al. Phase distribution of resin and fatty acids in colloidal wood pitch emulsions at different pH-levels. J Dispersion Sci Technol. 2009;30:912-919.

22. Zasadowski D, Hedenstrom E, Edlund $\mathrm{H}$, et al. Use of a voith flotation cell for removal of lipophilic extractives and $\mathrm{Mn}$ ions from spruce thermomechanical pulping process waters. BioRes. 2012;7:2784-2798. 
23. Meng F, Chae SR, Drews A, et al. Recent advances in membrane bioreactors (MBRs): Membrane fouling and membrane material. Water Res. 2009;43:1489-1512.

24. Wiesner MR, Aptel P. Mass transport and permeate flux and fouling in pressure-driven processes. Water treatment membrane processes, New York (NY): McGraw-Hill; 1996.

25. Cassano A, Donato L, Conidi C, et al. Recovery of bioactive compounds in kiwifruit juice by ultrafiltration. Innov Food Sci Emerg Technol. 2008;9:556-562.

26. Singleton VLRJA. Colorimetry of total phenolics with phosphomolybdic acid reagent. Am J Enol Vitic. 1965;16:144-158.

27. Dubois M, Gilles KA, Hamilton JK, et al. Colorimetric method for determination of sugars and related substances. Anal Chem. 1956;28:350-356.

28. Saththasivam J, Loganathan K, Sarp S. An overview of oil-water separation using gas flotation systems. Chemosphere. 2016;144:671-680.

29. Stack K, Lee R, Richardson D, et al. Complex formation and stability of colloidal wood resin pitch suspensions with hemicellulose polymers. Colloid Surf A: Physicochem Eng Asp. 2014;441:101-108.

30. Delcroix C, Bonnet JP, Etienne M, et al. Influence of ionic strength on membrane selectivity during the ultrafiltration of sulfated pentasaccharides. Carbohydr Polym. 2015;116:243248.

31. Allen LH. Characterization of colloidal wood resin in newsprint pulp. Pulp Pap Can. 1975;76: 139-146.

32. Nylund J, Sundberg K, Shen Q, et al. Determination of surface energy and wettability of wood resins. Colloid Surf Asp. 1998;133:261-268.

33. Sun RC, Sun XF, Wang SQ, et al. Ester and ether linkages between hydroxycinnamic acids and lignins from wheat, rice, rye, and barley straws, maize stems, and fast-growing poplar wood. Ind Crop Prod. 2002;15:179-188.

34. Iiyama K, Lam TBT, Stone BA. Phenolic acid bridges between polysaccharides and lignin in wheat internodes. Phytochem. 1990;29:733-737.

35. Whetten RW, MacKay JJ, Sederoff RR. Recent advances in understanding lignin biosynthesis. Annu Rev Plant Biol. 1998;49:585-609.

36. Boerjean W, Ralph J, Baucher M. Lignin biosynthesis. Annu Rev Plant Biol. 2003;54: 519-546.

37. Wong DW. Structure and action mechanism of ligninolytic enzymes. Appl Biochem Biotechnol. 2009;157:174-209.

38. Giacobbo A, Matos do Prado J, Meneguzzi A, et al. Microfiltration for the recovery of polyphenols from winery effluents. Sep Purif Technol. 2015;143:12-18.

39. Lawoko M, Henriksson G, Gellerstedt G. Characterisation of lignin-carbohydrate complexes (LCCs) of spruce wood (Picea abies L.) isolated with two methods. Holzforschung. 2006;60:156-161. 
40. Scalbert A, Monties B, Lallemand JY, et al. Ether linkage between phenolic acids and lignin fractions from wheat straw. Phytochem. 1985;24:1359-1362.

41. Willför S, Sjöholm R, Laine C, et al. Characterisation of water-soluble galactoglucomannans from Norway spruce wood and thermomechanical pulp. Carbohydr Polym. 2003;52: 175-187.

42. Strand E, Kallioinen M, Reinikainen SP, et al. Multivariate data examination in evaluation of the effect of the molecular mass of lignin and hemicelluloses on ultrafiltration efficiency. Sep Purif Technol. 2015;144:146-152. 
Table 1. Characteristics of fractions collected upstream and downstream flotation and 150, 5 and $1 \mathrm{kDa}$ filtration.

Table 2. Substances recovery rate for each step of flotation and membrane processes.

Figure 1. Schematic overall process.

Figure 2.Distribution of phenolic compounds in overall process.

Figure 3.Evolution of $150 \mathrm{kDa}$ membrane flux with and without flotation pretreatment under the same operating conditions (TMP process water at $60^{\circ} \mathrm{C}$, transmembrane pressure at 2.5 bars and cross flow velocity at $5 \mathrm{~m} \cdot \mathrm{s}^{-1}$ ).

Figure 4. Relative flux $\mathrm{J} / \mathrm{J}_{0}$ as a function of $\mathrm{VRF}$ for (a) $150 \mathrm{kDa}$, (b) $5 \mathrm{kDa}$ and (c) $1 \mathrm{kDa}$ filtrations of line 1 or 2 .

Figure 5. Distribution of membrane (RM), removable (Rremovable), irremovable (Rirremovable) and irreversible ( $\mathrm{R}$ irreversible) resistances of 150, 5, 1 (with $5 \mathrm{kDa}$ before) and $1 \mathrm{kDa}$ membranes

Figure 6. Fouling models 1 (a), 2 (b) and 3 (c) applied to $150 \mathrm{kDa}, 5 \mathrm{kDa}, 1 \mathrm{kDa}$ (line1) and $1 \mathrm{kDa}$ (line2) based on equations developed by Wiesner and Aptel [24]. 
Table 1. Characteristics of fractions collected upstream and downstream flotation and 150, 5 and $1 \mathrm{kDa}$ filtration.

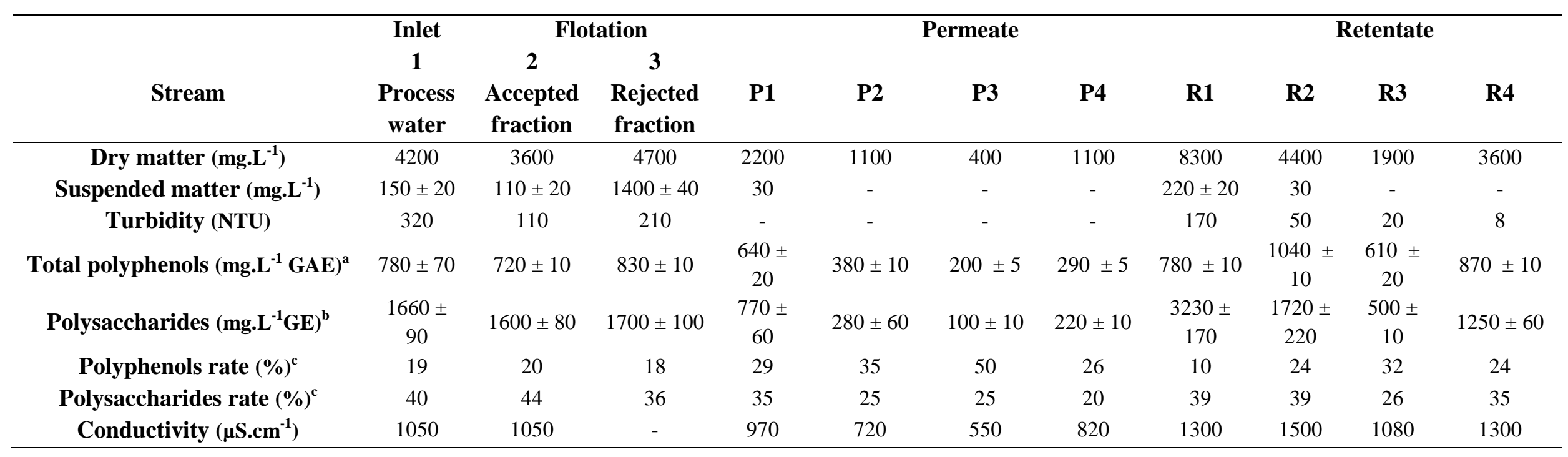

${ }^{\mathrm{a}} \mathrm{GAE}$ : gallic acid equivalent

${ }^{\mathrm{b}} \mathrm{GE}$ : glucose equivalent

${ }^{\mathrm{c}}$ Polysaccharides or Polyphenols rate $=($ Polysaccharides or Polyphenols concentration $/$ Dry matter concentration $)$ 
Table 2. Substances recovery rate for each step of flotation and membrane processes.

\begin{tabular}{cccccc}
\hline Substance/stream & $\begin{array}{c}\text { Flotation } \\
\text { rejected } \\
\text { fraction }(3) \\
(\%)\end{array}$ & $\begin{array}{c}\text { UF 150 kDa } \\
\text { retentate R1 } \\
(\%)\end{array}$ & $\begin{array}{c}\text { UF 5 kDa } \\
\text { retentate } \\
\text { R2 }(\%)\end{array}$ & $\begin{array}{c}\text { NF 1 kDa } \\
\text { retentate R3 } \\
(\%)\end{array}$ & $\begin{array}{c}\text { Line 2 } \\
\text { retentate R4 } \\
(\%)\end{array}$ \\
\hline Dry matter & 46 & 30 & 12 & 5 & 19 \\
Suspended matter & 39 & 22 & 2 & - & - \\
Total polyphenols & 44 & 15 & 15 & 9 & 24 \\
Polysaccharides & 42 & 29 & 6 & 2 & 9 \\
\hline
\end{tabular}




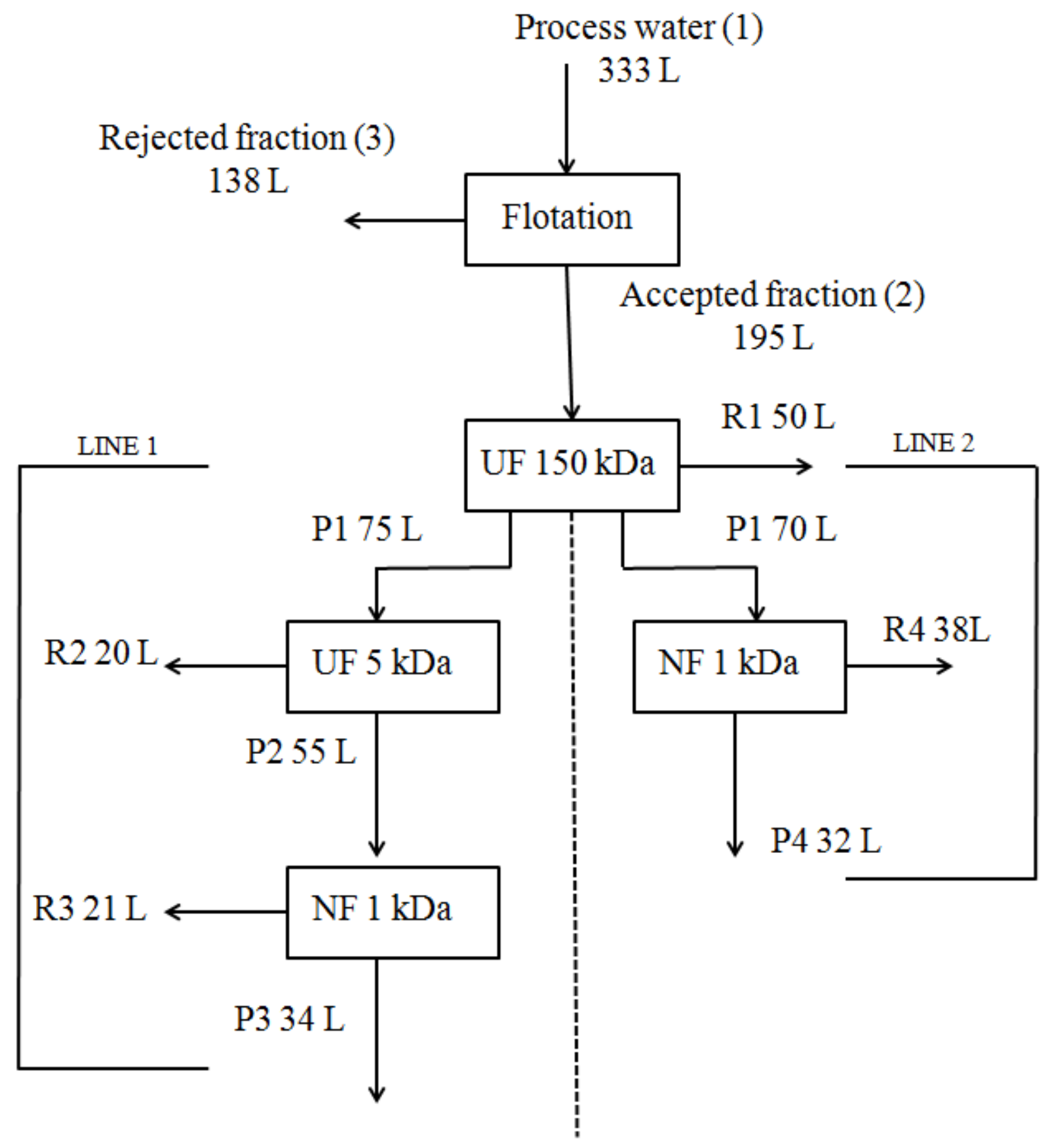

Figure 1. Schematic overall process. 


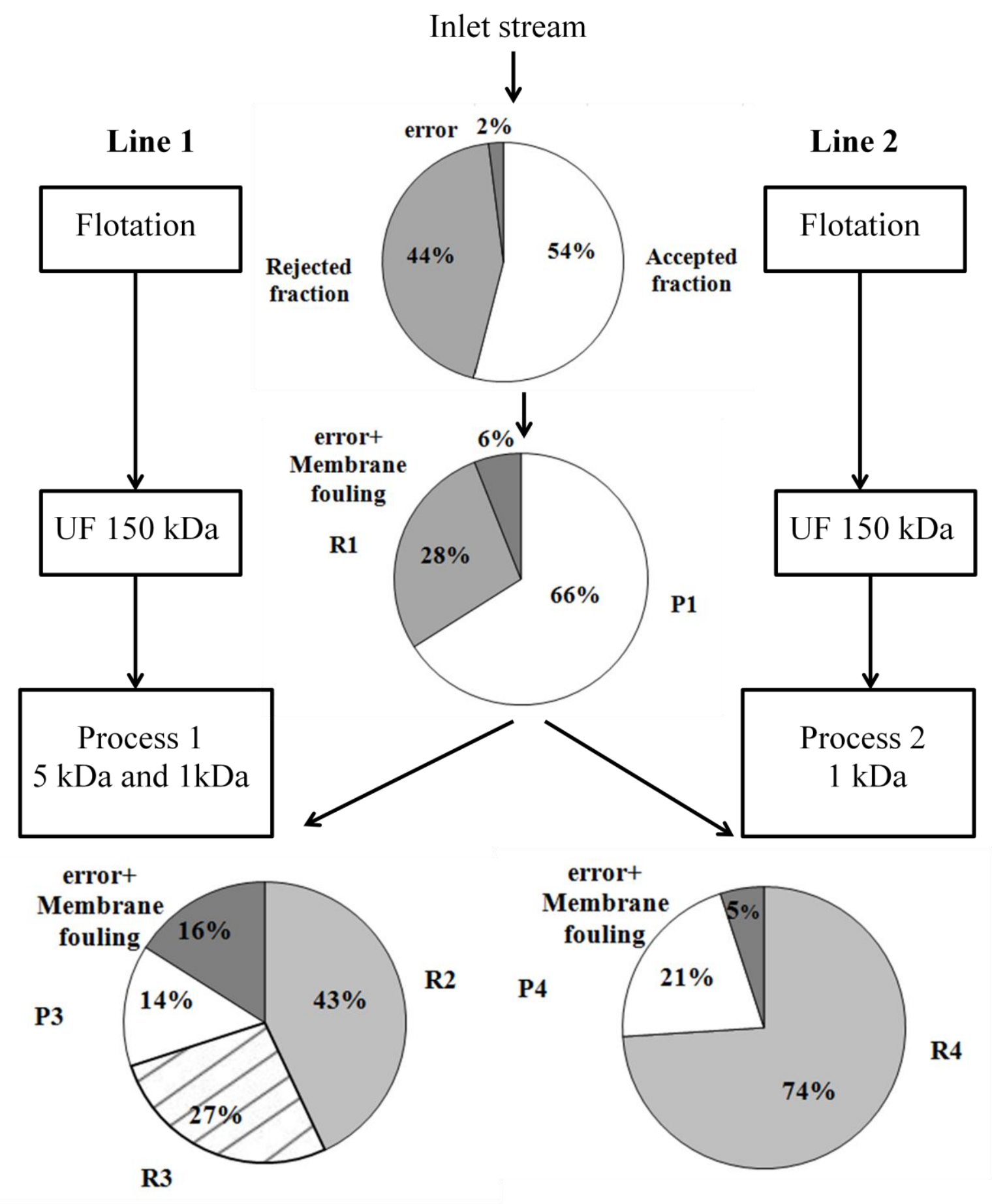

Figure 2.Distribution of phenolic compounds in overall process. 


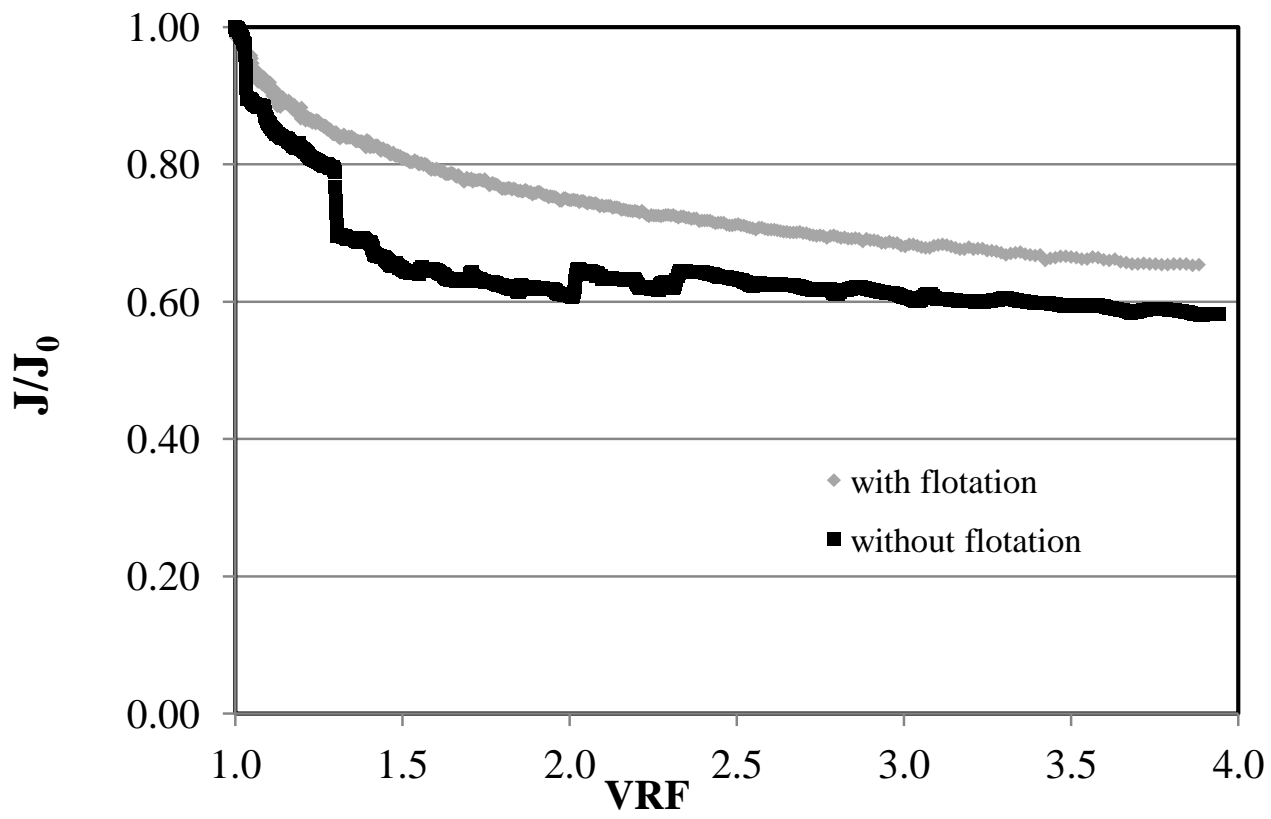

Figure 3.Evolution of $150 \mathrm{kDa}$ membrane flux with and without flotation pretreatment under the same operating conditions (TMP process water at $60^{\circ} \mathrm{C}$, transmembrane pressure at 2.5 bars and cross flow velocity at $5 \mathrm{~m} \cdot \mathrm{s}^{-1}$ ). 
$\mathbf{a}$

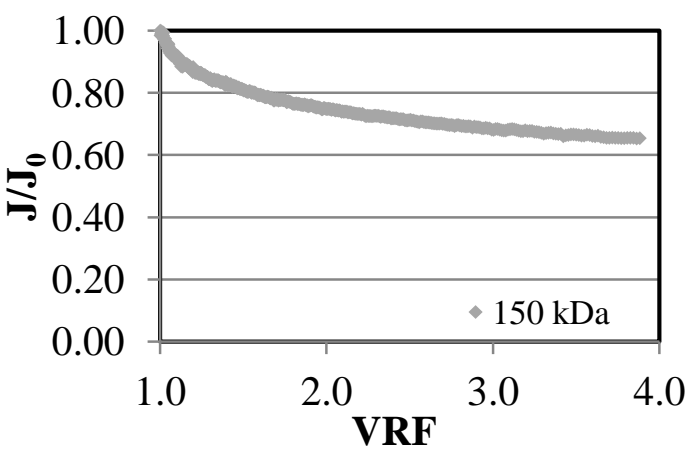

b

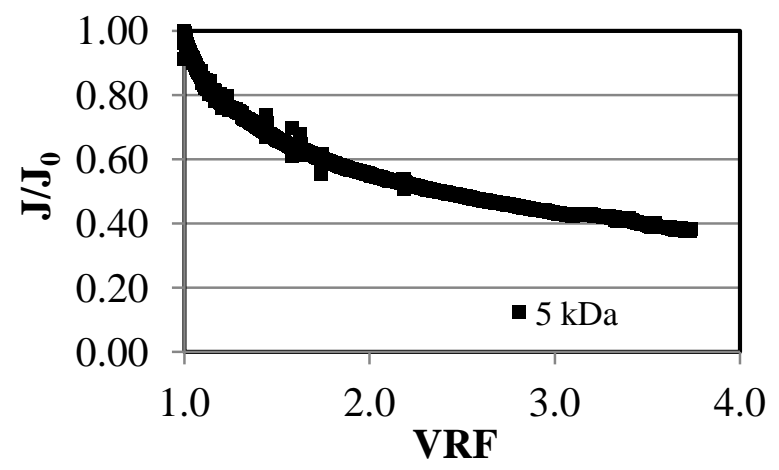

c

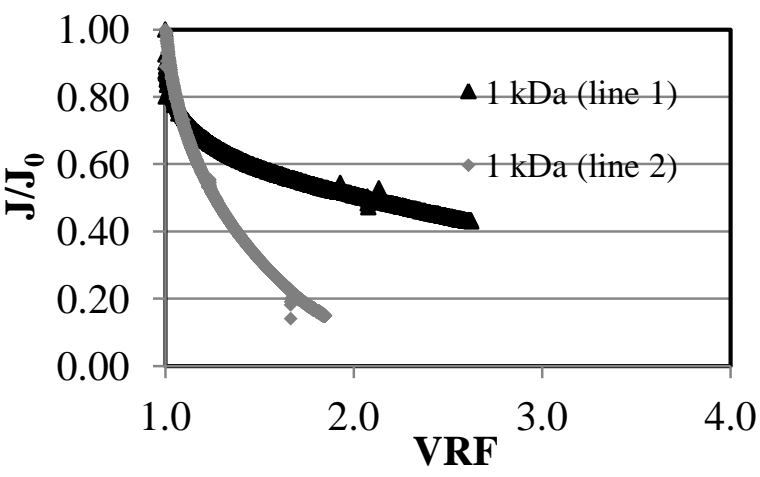

Figure 4. Relative flux $\mathrm{J} / \mathrm{J}_{0}$ as a function of $\mathrm{VRF}$ for (a) $150 \mathrm{kDa}$, (b) $5 \mathrm{kDa}$ and (c) $1 \mathrm{kDa}$ filtrations of line 1 or 2. 


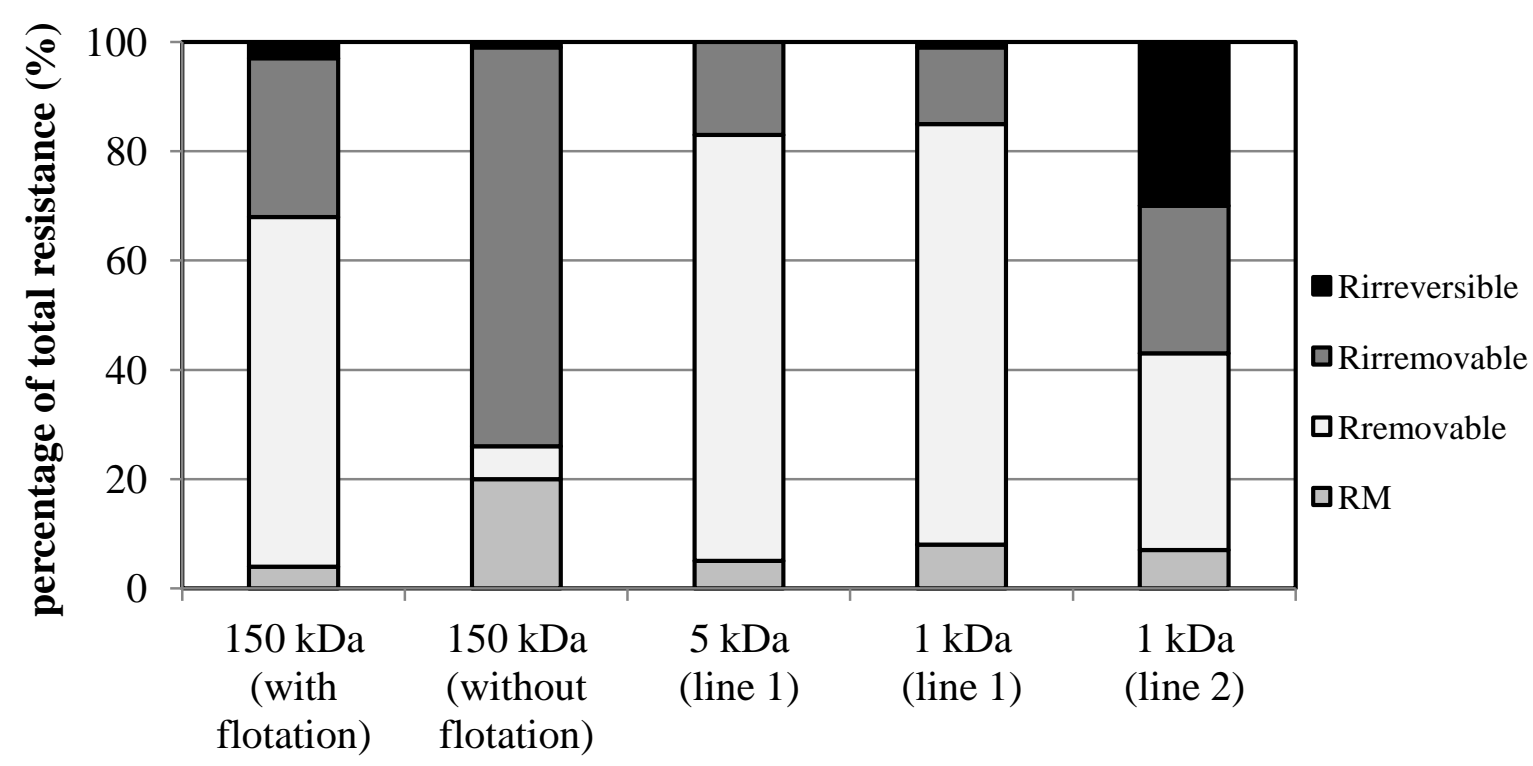

Figure 5. Distribution of membrane (RM), removable (Rremovable), irremovable (Rirremovable) and irreversible ( $\mathrm{R}$ irreversible) resistances of 150, 5, 1 (with $5 \mathrm{kDa}$ before) and $1 \mathrm{kDa}$ membranes 


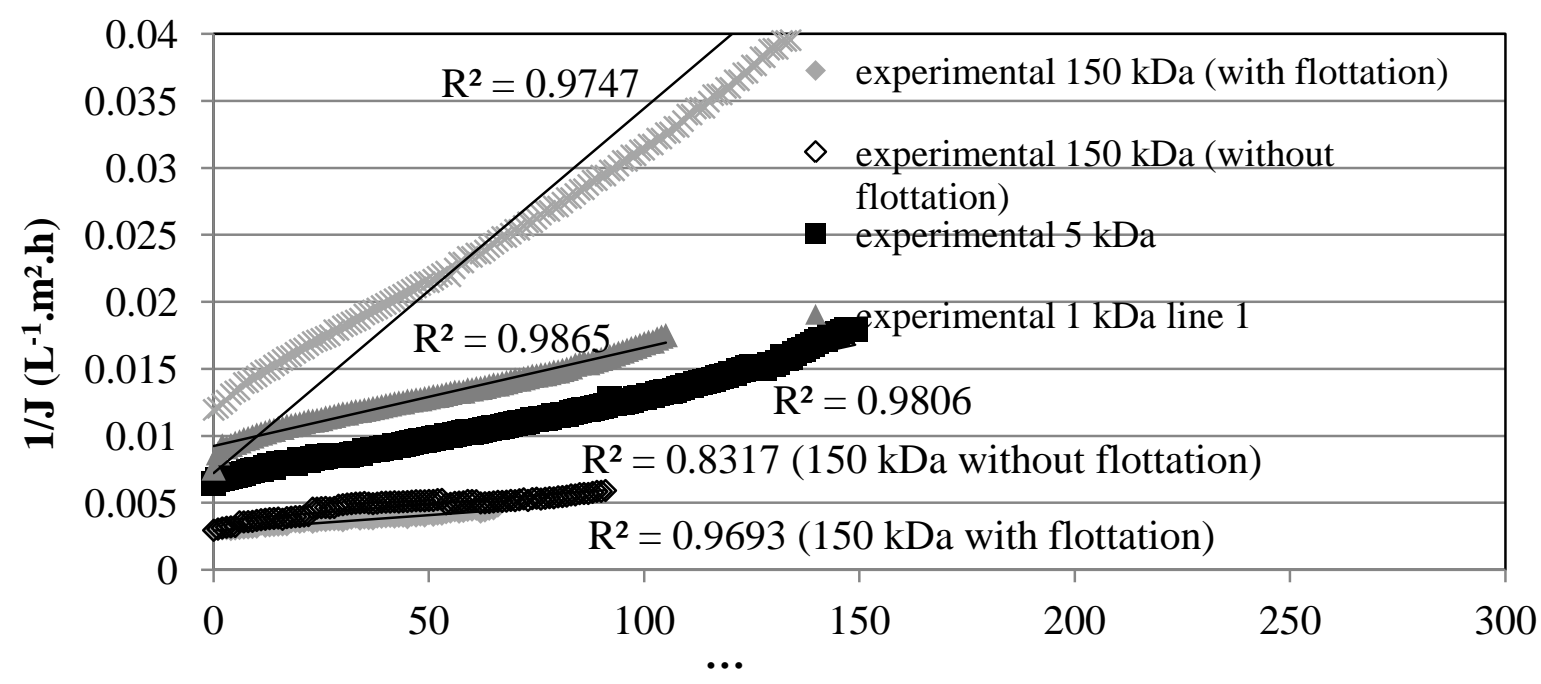

b

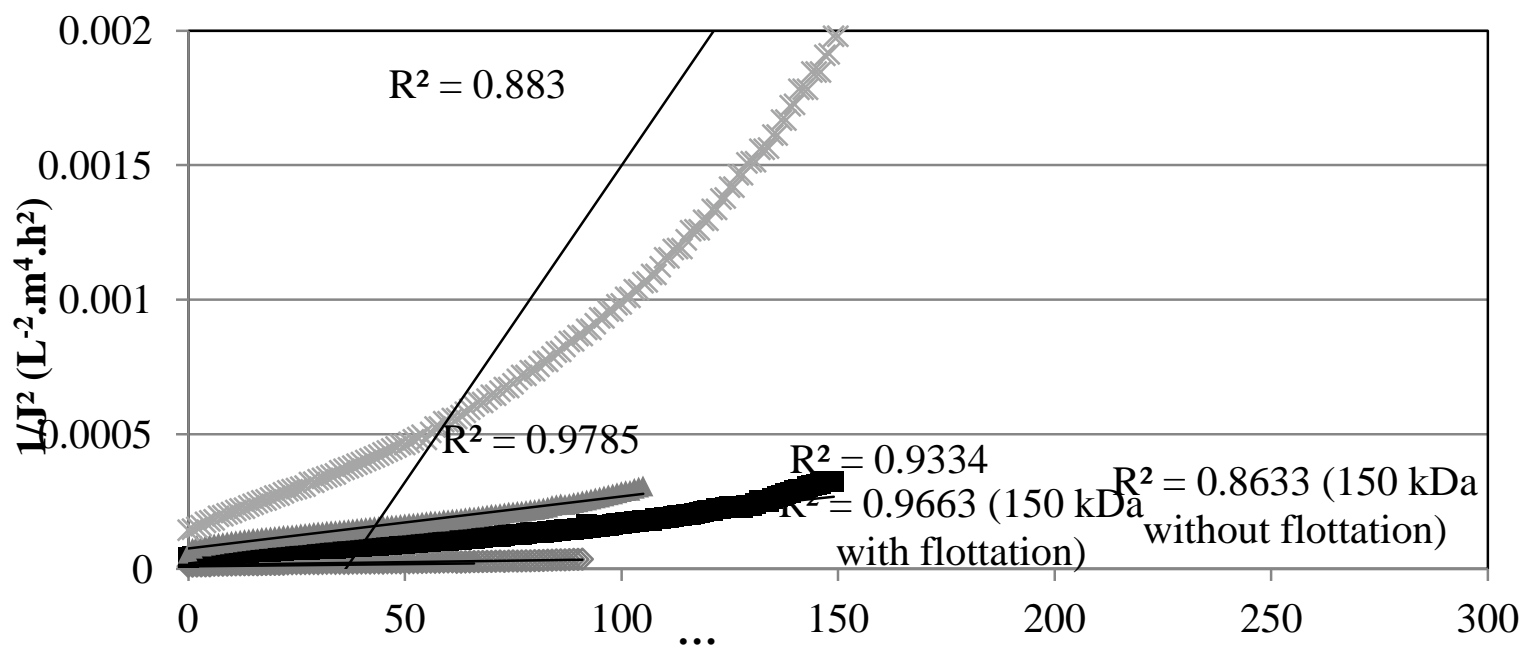

c

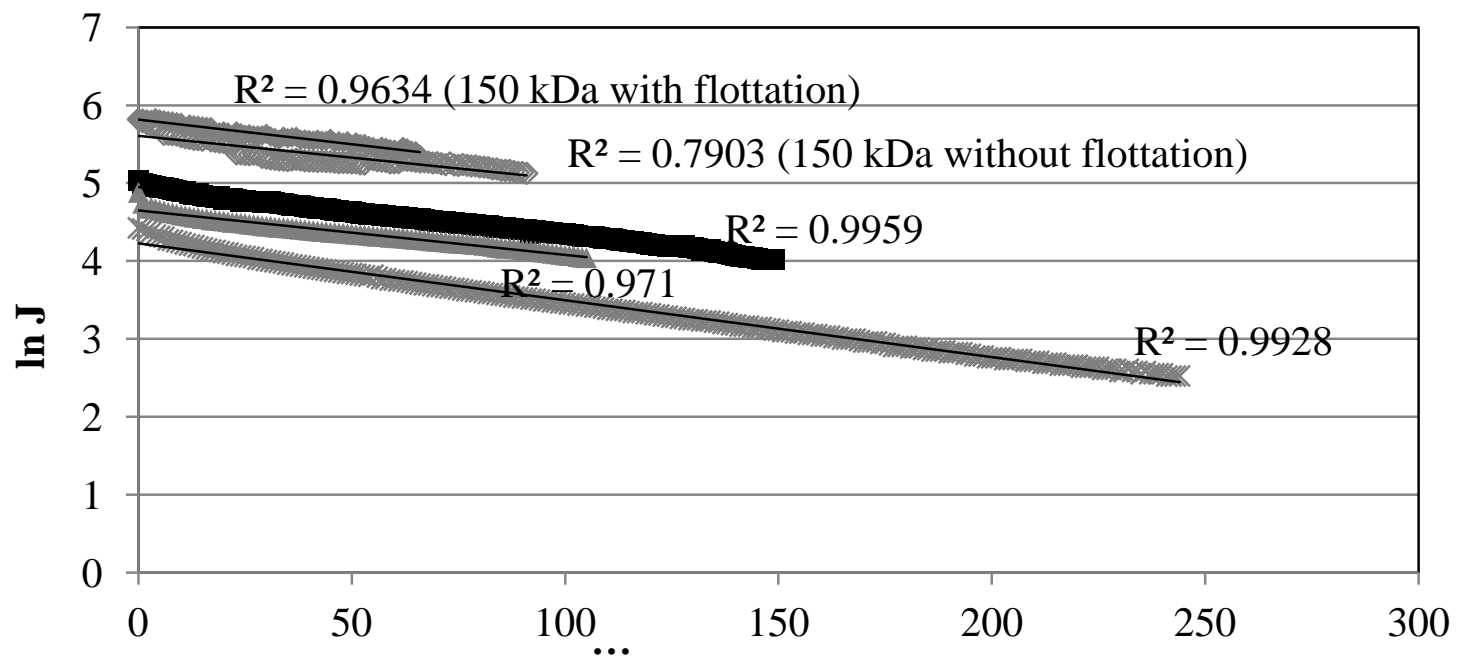

Figure 6. Fouling models 1 (a), 2 (b) and 3 (c) applied to $150 \mathrm{kDa}, 5 \mathrm{kDa}, 1 \mathrm{kDa}$ (line1) and $1 \mathrm{kDa}$ (line2) based on equations developed by Wiesner and Aptel [24]. 